\title{
A escatologia do amor: a esperança na compreensão trinitária de Deus em Jürgen Moltmann
}

\author{
Orientador: Cesar Augusto Kuzma \\ Mestrando: Rogério Guimarães de Almeida Cunha \\ Área de Concentração: Teologia Sistemático-Pastoral
}

Linha de Pesquisa: Fé e Cultura

A escatologia do amor é o estudo da escatologia de J. Moltmann a partir da sua compreensão de Deus na história do sofrimento do mundo e na história do sofrimento solidário de Deus por este mundo. Amor é o conceito cristão de Deus como Trindade que se move desde o seu futuro em direção à sua criação. Trata-se do Deus Amor que sofre (como Deus) solidariamente no sofrimento de sua criação. O Deus cristão não é apático, imóvel, mas amor. Este amor fundamenta a esperança, esta que é característica fundamental da fé cristã. A partir da passagem da escatologia de um discurso informativo para um discurso performativo, esta pesquisa aponta o dado biográfico da teologia de J. Moltmann e a implicação deste dado na compreensão de Deus desde o Evento Pascal de Cristo, que reflete o pathos divino na cruz de Cristo, solidário na situação de abandono e morte do homem, o sim de Deus a este Crucificado pela sua ressurreição e a irrupção em curso de seu futuro por obra do Espírito Santo. Desde esta perspectiva, a existência cristã como informada pela esperança se fundamenta nesse amor revelador de Deus. Esta pesquisa parte da pergunta por Deus e pela esperança em J. Moltmann, segue aprofundando a compreensão moltmanniana de Deus e reflete o enunciado escatológico desta compreensão de Deus como Trindade, cujo amor invitativo liberta, transforma e integra, caracterizando a fé cristã e sua práxis como um dado escatológico.

Palavras-chave: Trindade. Amor invitativo. Sofrimento solidário. 